\title{
Innovative energy-related use of shallow and deep groundwaters - Examples from China and Switzerland
}

\section{Ladislaus Rybach*}

Institute of Geophysics ETH, Zürich, Switzerland

Received: January 28, 2015; accepted: January 28, 2015

The heat content of shallow or deep aquifers can be used for space heating. Two innovative systems are described below in detail: a geothermal heat pump system based on a single well in China (= shallow), and a cascading use of tunnel waters (= deep) in Switzerland. The "Single Well System" (HYY SWS) was invented and developed by Beijing Ever Source Science \& Technology Development Co., Ltd (HYY) to provide buildings with heating and cooling as well as with domestic hot water. The powerful system operates at about $500 \mathrm{kWth}$ capacity. Unlike traditional groundwater heat pump systems, in which two wells are used (one for pumping groundwater out and the other to dispose of cooled water), the HYY SWS uses only one, specially designed well for production and reinjection. A borehole with a depth of about $70-80 \mathrm{~m}$ and a diameter of $0.5 \mathrm{~m}$ is drilled for HYY Single Well Systems. The necessary local geologic site condition is to have a shallow aquifer with a hydraulic conductivity of $10^{-3} \mathrm{~m} / \mathrm{sec}$ or higher. Many such systems operate now in China, several of which, for instance, serve the 2008 Summer Olympic Facilities in Beijing. Switzerland has, in its mountainous parts, hundreds of deep tunnels. Tunnels drain the rock overburden and, depending on its thickness, water temperatures up to $50{ }^{\circ} \mathrm{C}$ can be encountered and utilized. The most straightforward and cheapest form of tunnel heat usage is to collect and transport inflowing waters via ducts to the portals, with as little temperature drop as possible. The thermal power depends on flow rate and temperature. At or near the portals the heat content of the waters can be used for various applications. When the temperature level of the tunnel water outflows is too low for direct applications (e.g. for district heating), heat pumps are employed. From Switzerland a whole suite of uses can be reported: space heating, greenhouses, balneology and wellness, fish farming. At the northern portal of the $35 \mathrm{~km}$ long Loetschberg base tunnel at Frutigen, the tunnel water is used subsequently ("cascading") for space heating, greenhouse, and fish farming (incl. caviar production).

Keywords: shallow aquifers, geothermal heat pumps, space heating and cooling, tunnels draining mountains, greenhouses and fish ponds

\footnotetext{
* Corresponding address: Sonneggstrasse 5, 8092 Zürich, Switzerland;
}

E-mail: rybach@ig.erdw.ethz.ch 


\section{Shallow single well system}

\section{Introduction}

The Beijing-based company "Beijing Ever Source Science and Technology Development Co., Ltd.” (HYY) originally developed the new, powerful groundwater heat pump system ("HYY Single Well System (SWS) of Supplying and Returning Water") for the Beijing area in China. The new technology, developed by HYY, uses groundwater to provide heating for buildings in winter and cooling in summer. Usually a groundwater heat pump system operates with two wells-extraction and reinjection. The powerful HYY system operates with a large diameter $(0.5 \mathrm{~m})$ single well at about $600 \mathrm{kWth}$ capacity. Domestic hot water is also supplied. The system works in a sustainable manner with a high efficiency and also provides cooling, without evaporation (Xu and Rybach 2003). The hydrogeologic prerequisites and environmental and economic benefits were compiled by Xu and Rybach (2004), along with monitoring results to prove that the operating systems have no effect on groundwater properties such as quality. The HYY SWS operational principle is summarized below, its high efficiency is documented, and examples of applications from China and from abroad are presented.

\section{The HYY single well system}

The HYY SWS uses "state-of-the-art surface" equipment, which consists of customary components like pumps, valves, heat exchangers, storage tanks, heat pumps, and control instrumentation. The innovative, basic, and powerful unit of the SWS is its subsurface component, the "Single Well". Unlike traditional groundwater heat pump systems, in which two wells are used (one for pumping groundwater out and the other to dispose of cooled water), the HYY SWS uses one specially designed well for production and reinjection.

The necessary local geologic site condition is to have a powerful shallow aquifer (depth range $20-100 \mathrm{~m}$, water table depth $<30 \mathrm{~m}$ ) with a hydraulic conductivity of $10^{-3} \mathrm{~m} / \mathrm{sec}$ or higher, flow velocities $0.5-1 \mathrm{~m} /$ day, constant groundwater temperatures $\left(12-15^{\circ} \mathrm{C}\right)$; see $\mathrm{Xu}$ and Rybach (2003).

A borehole with a depth of about $70-80 \mathrm{~m}$ and a diameter of $0.5 \mathrm{~m}$ is drilled for HYY Single Well Systems. A schematic diagram of the HYY SWS is shown in Fig. 1. Groundwater at a temperature of about $10-15{ }^{\circ} \mathrm{C}$ is pumped from the well (its lower, water production space) at a flow rate of about $50-100 \mathrm{~m}^{3} / \mathrm{h}$ and passes through a wellhead heat exchanger, where the return water from the heat pump receives heat from the groundwater. The heat pump supplies water at a temperature of about $50-55^{\circ} \mathrm{C}$ to the fan coils for space heating, and the temperature of the water reinjected into the well is lowered to about $5-10^{\circ} \mathrm{C}$. The water then flows to the upper return space $(\sim 30 \mathrm{~m})$ of the well in a return pipe. Due to the blocking functions of clapboards 1 and 2, this water cannot directly enter the lower part of the well (low 


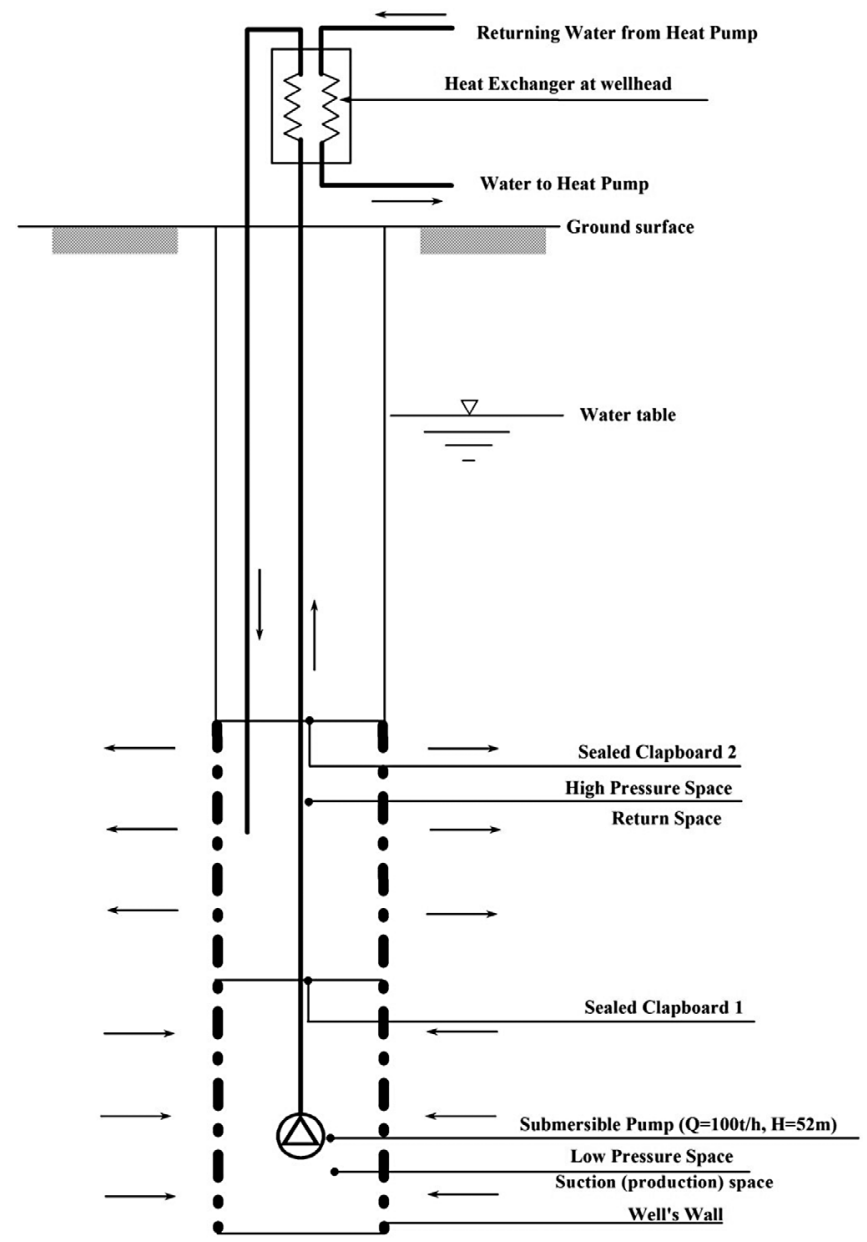

Fig. 1

HYY Single Well System (SWS) for production from and reinjection into an aquifer. The lower part of the well, below clapboard 2, surrounded by a slotted wall, consists of an upper pressurized reinjection section between clapboards 1 and 2 and a deeper low-pressure water production section beneath clapboard 1 (from Xu and Rybach 2010)

pressure section, $\sim 20 \mathrm{~m}$ ) but leaves the well through special metal meshes in the slotted well wall (patent holder: HYY) and takes heat from the surrounding sand and gravel. This allows the water to return to its original temperature of $10-15{ }^{\circ} \mathrm{C}$ underground in the vicinity of the well over time. This water then flows back into the production (low pressure) space of the well, thus sustaining the heat balance in the groundwater. The maximum thermal power of a single well is about $0.6 \mathrm{MWth}$. In the summertime, "direct cooling" (i.e. with heat pump switched off) is provided by the groundwater after heat exchange. 


\section{Efficiency comparison with other geothermal direct usage types}

Regardless of its size, the HYY Single Well System (SWS) provides a very substantial geothermal supply capacity (several hundreds of $\mathrm{kW}$ ). A comparison with other similar usage types (conventional groundwater heat pumps, borehole heat exchangers, standing column wells, boreholes into deep aquifers) demonstrated the great efficiency of the HYY SWS. For this comparison, the specific thermal power capacity (W/m of borehole length) was calculated. The HYY SWS had the highest value by far, clearly demonstrating its superiority. The thermal capacity of the typical HYY SWS was $7500 \mathrm{~W} / \mathrm{m}$, compared to $1800 \mathrm{~W} / \mathrm{m}$ for wells in deep aquifers, $1000 \mathrm{~W} / \mathrm{m}$ for typical conventional groundwater heat pumps, $532 \mathrm{~W} / \mathrm{m}$ for standing column wells (USA average), and $50 \mathrm{~W} / \mathrm{m}$ for borehole heat exchanger-coupled heat pumps with average boreholes (details in Xu and Rybach, 2006). In addition to the high specific capacity of this system, the relatively small drilling depth required is an important advantage. Drilling deeper for the installation of other systems (except for the conventional groundwater heat hump system) is more costly and risky.

\section{Examples of application, operational experience in China and abroad}

The HYY SWS can be applied to a wide variety and scale of buildings. Successful applications in various parts of China encompass a correspondingly wide range of building types and purposes: residential buildings (single family houses and apartments), office buildings, hotels, hospitals, factories, shopping centers, and schools. Such examples are described in detail by Xu and Rybach (2010). Operational experience was analyzed, and the positive results were reported by $\mathrm{Xu}$ and Rybach (2006). The various utilization possibilities are evident. A special demonstration of versatility is the application of this design to de-ice the $35,000 \mathrm{~m}^{2}$ "Waterscape" pond in wintertime at the National Center for the Performing Arts in Beijing (Xu et al. 2008).

There are also successful HYY Single Well System realizations outside of China, in USA as well as in Mongolia; see Xu et al. (2006). The realizations at the 2008 Beijing Olympics gained special attention. Some details about them are given below.

\section{HYY Single well Systems at the 2008 Beijing Olympic Park}

The HYY Single Well Systems deployed at the 2008 Beijing Olympic Park deserve special attention (Rybach and $\mathrm{Xu}$ 2008). Heating and cooling of various buildings and installations are supplied by HYY SWS, as shown in Table 1.

A photograph of the Scientific Research building is provided in Fig. 2. The supply and return temperatures during the 2008/2009 heating season by the heat pump in the Athlete Mansion Hotel $\left(27,532 \mathrm{~m}^{2}\right)$ and Scientific Research Building $\left(36,850 \mathrm{~m}^{2}\right)$ are given in Tables 2 and 3, respectively.

The observed temperatures and their evolution through time show similarities, whereas the different electricity consumptions reflect the different building sizes. 
Table 1

Facilities of the 2008 Beijing Olympic Park, supplied by HYY SWS installations

\begin{tabular}{lc}
\hline Facility & Area $\mathrm{m}^{2}$ \\
\hline Olympic Village National Gymnasium & 80000 \\
\hline $\begin{array}{l}\text { Athlete Mansion Hotel and Scientific } \\
\text { Research Building }\end{array}$ & 64382 \\
\hline $\begin{array}{l}\text { Tennis Center } \\
\text { Hockey Training Facility in Beijing }\end{array}$ & 26541 \\
$\begin{array}{l}\text { Lucheng Sports School } \\
\text { Bicycle Training Facility in Beijing }\end{array}$ & 6049 \\
$\begin{array}{l}\text { Lucheng Sports School } \\
\text { National Great Theatre Waterscape }\end{array}$ & 35000 \\
\hline $\begin{array}{l}\text { Water antifreeze facility in a pool near } \\
\text { the National Swimming Center }\end{array}$ & 3000 \\
\hline
\end{tabular}

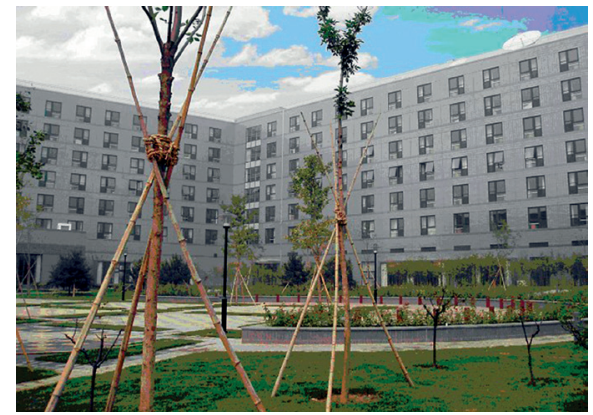

Fig. 2

Scientific Research Building at Beijing 2008 Olympics Park (Photo: HYY Co., Beijing)

Table 2

Input/output temperatures (in ${ }^{\circ} \mathrm{C}$ ) and electricity consumption (in MWh) for the 2008/2009 heating season by the heat pump in the Athlete Mansion Hotel (27,532 $\left.\mathrm{m}^{2}\right)$, Beijing 2008 Olympic Park

\begin{tabular}{lllcccc}
\hline Heat pump & & November & December & January & February & March \\
\hline \multirow{2}{*}{ Evaporator } & Input & 14.7 & 14.8 & 12.5 & 13.5 & 13.1 \\
\cline { 2 - 6 } & Output & 10.7 & 10.0 & 8.3 & 8.7 & 8.4 \\
\hline \multirow{2}{*}{ Condenser } & Input & 37.6 & 40.4 & 41.2 & 42.3 & 39.5 \\
\cline { 2 - 6 } & Output & 41.7 & 44.7 & 44.9 & 46.5 & 43.0 \\
\hline Electricity consumption & 83.3 & 214.3 & 203.8 & 165.2 & 79.6 \\
\hline
\end{tabular}

Table 3

Input/output temperatures (in ${ }^{\circ} \mathrm{C}$ ) and electricity consumption (in MWh) for the 2008/2009 heating season by the heat pump in the Scientific Research Building $\left(36,850 \mathrm{~m}^{2}\right)$, Beijing 2008 Olympic Park

\begin{tabular}{llccccr}
\hline Heat pump & & November & December & January & February & March \\
\hline \multirow{2}{*}{ Evaporator } & Input & 15.4 & 13.6 & 12.3 & 12.7 & 13.1 \\
\cline { 2 - 7 } & Output & 10.5 & 9.8 & 8.4 & 8.3 & 8.7 \\
\hline \multirow{2}{*}{ Condenser } & Input & 39.1 & 38.6 & 39.1 & 39.1 & 40.7 \\
\cline { 2 - 7 } & Output & 43.6 & 43.0 & 43.3 & 43.9 & 44.5 \\
\hline Electricity consumption & 114.6 & 284.8 & 330.0 & 249.8 & 105.4 \\
\hline
\end{tabular}




\section{Environmental benefits}

Geothermal heat pumps (GHP) currently represent the fastest growing branch of geothermal energy utilization (Rybach 2005). The innovative "Single Well System" (HYY SWS) of Beijing Ever Source Science and Technology Development Co., Ltd (HYY) belongs to this category. Thus, the use of HYY SWS technology also represents an important contribution to the renewable energy field and the mitigation of climate change, as the increasing use of the environmentally friendly geothermal technology enables the decrease of great amounts of fossil fuel use and the avoidance of corresponding $\mathrm{CO}_{2}$ emissions. In the case of the application of GHP systems in building renovation, this results in significant emission reduction. It can be expected that the application of GHP systems, along with other geothermal technologies (especially for power generation), will further benefit future generations.

\section{Shallow system: conclusions}

The HYY SWS uses low-temperature geothermal energy from the shallow ground and thus does not require expensive deep drilling. Groundwater is used as the heat transfer fluid, enabling sustainable operation. The HYY SWS is a closed-circuit system that is free of the emission of any gas, solid or liquid pollutants. The widespread application of this system will decrease the use of fossil fuels, increase the efficiency of renewable energy utilization, and promote environmental protection, while minimizing the cost of geothermal energy development.

The HYY SWS is superior in efficiency when compared to other types of applications (conventional groundwater heat pumps, borehole heat exchangers, standing column wells, and boreholes into deep aquifers). It delivers a highly flexible system to provide space heating, cooling, and domestic hot water to a wide variety of buildings. In fact, HYY SWS are now operating in a wide range of building types and sizes in many parts of China. The operational experiences are excellent and include installations at the Beijing 2008 Olympic Park.

The system is now ready for worldwide implementation. After installing and operating a system in Mongolia in 2006, the first HYY SWS operation in the USA was initiated in Baker City, Oregon in 2007; details see in Xu and Rybach (2010). The latter demonstrates that licensing does not present a problem, even in countries and regions in which this innovative technology has not yet been deployed.

\section{Deep system}

\section{Introduction}

Tunnels drain the rock overburden and, depending on its thickness, in mountainous Switzerland water temperatures up to $50{ }^{\circ} \mathrm{C}$ can be encountered and utilized (Rybach 2010). In planning the tunnels the following must be considered: higher in- 
flow rates and temperatures are better for energy usage, whereas for the geotechnical tunneling work such inflows are more of a disadvantage. Thus careful consideration/ optimization is required as to what extent the water inflows are accepted or retention measures (like cementing the tunnel walls) are applied.

Water inflows to deep tunnels usually originate from permeable fractures/fracture zones. According to hydrogeologic experience the temperature of the inflowing waters corresponds (except for a few exceptions) to the rock temperature at the entry point (see Fig. 3). The initially higher inflow rates usually stabilize over the course of time at significantly lower levels (Rybach 1995).

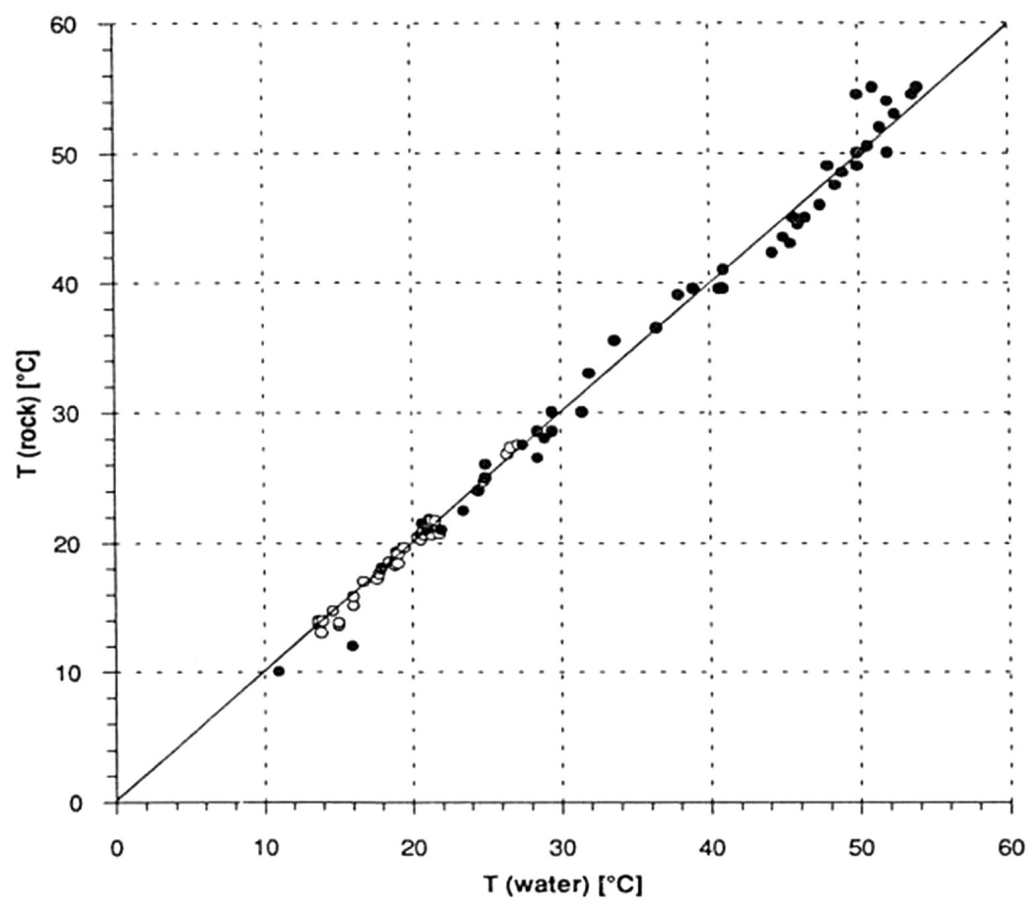

Fig. 3

Tunnel wallrock temperature and temperature of the inflowing water. Data from the Simplon Rail Tunnel (points) and the Gotthard Road Tunnel (circles). The line marks 100\% correlation; the best straight line through the measurement points has a regression coefficient of 0.996 (from Rybach 1995)

The most straightforward and cheapest form of tunnel heat usage is to collect and transport inflowing waters via ducts to the portals, with as little temperature drop as possible. The thermal power depends on flow rate and temperature. At or near the portals the heat content of the waters can be used for various applications. When the temperature level of the tunnel water outflows is too low for direct applications (e.g. for district heating), heat pumps are employed. 


\section{Available thermal power}

The thermal capacity and the exit temperature at the portal are decisive for the use of the tunnel water in energy terms. The thermal capacity P (e.g. in Megawatt thermal, MWth ) is given by

$\mathrm{P}=\mathrm{c} \mathrm{Q} \Delta \mathrm{T}$

where

$\mathrm{c}$ is the thermal capacity of water $(\mathrm{J} / 1, \mathrm{~K})$,

$\mathrm{Q}$ the outflow rate (1/s) and

$\Delta \mathrm{T}(=\mathrm{T}-\mathrm{To})$ the useful temperature drop. $\mathrm{T}$ is the outflow temperature and To the reference temperature, i.e. the temperature of the water after heat extraction.

The expected thermal capacities and outflow temperatures are usually assessed in the tunnel planning phase. Analytical calculations are required for this purpose. Numerical, finite element, three-dimensional, non-stationary simulation models are employed for the prediction; in this the hydraulic and thermal boundary conditions are especially important. Such a prognosis, for instance, was undertaken for the Koralm Project in Austria (Graf et al. 2002).

A factor influencing the outflow temperature is the way the tunnel water is collected and conducted to the portal of the tunnel. The general layout and the material of the drainage system, including thermal isolation, water flow-rate and temperature inside the tunnel, are factors influencing the temperature of the drained tunnel water.

The cooling of water flowing in a buried pipe can be calculated by the following formula:

$\mathrm{T}(\mathrm{L})=\mathrm{T}_{\mathrm{b}}+\left(\mathrm{T}_{\mathrm{b}}+\mathrm{T}_{\mathrm{t}}\right) \exp [-(\mathrm{K} / \mathrm{Qc}) \mathrm{L}]$

where

$\mathrm{L}$ is the length of the pipe,

$\mathrm{T}_{\mathrm{b}}$ the temperature of the water at the beginning of the pipe,

$\mathrm{T}(\mathrm{L})$ the temperature of the water at the end of the pipe,

$\mathrm{T}_{\mathrm{t}}$ the temperature in the tunnel,

$\mathrm{Q}$ the water flow rate $(1 / \mathrm{sec})$,

$\mathrm{K}$ the heat transfer coefficient $(\mathrm{W} / \mathrm{mK})$, and

$\mathrm{c}$ the specific thermal capacity of water.

As an example, tunnel water of $35^{\circ} \mathrm{C}$ flowing at $50 \mathrm{l} / \mathrm{sec}$, in a $70 \mathrm{~cm}$-diameter cement pipe, buried $50 \mathrm{~cm}$ deep, will be cooled by $5{ }^{\circ} \mathrm{C}$ over a distance of $20 \mathrm{~km}$, when the temperature in the tunnel is $25^{\circ} \mathrm{C}$. The cooling is reduced to $1{ }^{\circ} \mathrm{C}$ by applying a Flumrock ${ }^{\circledR}$ insulation of $5 \mathrm{~cm}$ thickness (Wilhelm and Rybach 2003). 


\section{Environmental aspects}

Should the outflowing tunnel water not be used for energy-related purposes, it would be diverted to surface waters. Water protection regulations in Switzerland limit such discharge: a river must not be heated up by more than $1.5^{\circ} \mathrm{C}\left(=\Delta \mathrm{T}_{\text {reg }}\right)-$ given its lowest watermark. The maximum permitted inflow $\mathrm{Q}_{\max }$ can be calculated as follows:

$\mathrm{Q}_{\max }=\Delta \mathrm{T}_{\mathrm{reg}} \mathrm{Q}_{\mathrm{rmin}} /\left(\mathrm{T}_{\mathrm{p}}-\mathrm{T}_{\mathrm{rmin}}-\Delta \mathrm{T}_{\mathrm{reg}}\right)$

where

$\mathrm{Q}_{\mathrm{rmin}}$ is the minimum delivery of the nearest river,

$\mathrm{T}_{\min }$ is the minimum river water temperature at that time, and

$\mathrm{T}_{\mathrm{p}}$ the temperature of the tunnel water at the portal.

Often the locally accessible rivers can take up only limited flow rates. As a consequence, cooling ponds or even cooling towers would have to be installed without application to energy production, at least during the construction phase. The tunnel company is thus essentially interested in the energy-related use of the outflowing water. The prerequisite of thermal use is the presence of heat consumers close to the portals.

\section{Examples of application}

Switzerland has more than 700 road or rail tunnels. Owing to substantial overburden the water inflow temperature can reach $40-50{ }^{\circ} \mathrm{C}$. A usage-potential study assessed a selection of 150 tunnels, of which 15 were more closely examined (Rybach et al. 2003). The thermal potential of these 15 tunnels amounts to roughly $30 \mathrm{MWt}$. Flow rates vary between $3601 / \mathrm{min}$ and 24,000 1/min and outflow temperatures at the portals from $11.9{ }^{\circ} \mathrm{C}$ to $24.3{ }^{\circ} \mathrm{C}$. The flow rates are practically constant throughout the year, just like the water temperatures. As far as the use of energy is concerned, traditional space heating is primarily involved; however, this depends on sufficient thermal consumers located close to the portals. Should these be lacking, other, innovative solutions can be taken into consideration. Both variants will be discussed in the following.

\section{Space heating with tunnel waters}

Currently tunnel heat utilization for heating purposes is taking place at five locations (as indicated in Table 4), in the Swiss Jura and in the Swiss Alps. These are heating facilities, which utilize tunnel heat by means of heat pumps: the Gotthard Road Tunnel, Furka Rail Tunnel, Mappo-Morettina Road Tunnel, Hauenstein Rail Tunnel, Ricken Rail Tunnel, and finally the Grand St. Bernard Tunnel, in which the 
Table 4

The geothermal potential and usage of some Swiss Alpine tunnels (from Rybach et al. 2003)

\begin{tabular}{|c|c|c|c|c|c|}
\hline Name/location & Canton & Type of tunnel & $\begin{array}{l}\text { Water discharge } \\
{[1 / \mathrm{min}]}\end{array}$ & $\begin{array}{l}\text { Temperature } \\
\text { of water }\left[{ }^{\circ} \mathrm{C}\right]\end{array}$ & $\begin{array}{l}\text { Heating } \\
\text { capacity } \\
{[\mathrm{kW} \text { th }]^{1}}\end{array}$ \\
\hline Ascona & TI & Road & 360 & 12 & 150 \\
\hline Furka ${ }^{2}$ & VS & Railway & 5400 & 16 & 3’758 \\
\hline Frutigen $^{2}$ & $\mathrm{BE}$ & Investigation tunnel & 800 & 17 & 612 \\
\hline Gotthard $^{2}$ & TI & Road (N2) & 7200 & 15 & 4'510 \\
\hline Grenchenberg (South portal) & $\mathrm{SO}$ & Railway & 18000 & 10 & $11^{\prime} 693$ \\
\hline Hauenstein (Base tunnel) & $\mathrm{SO}$ & Railway & 2500 & 19 & $2 ’ 262$ \\
\hline Isla Bella & GR & Road & 800 & 15 & 501 \\
\hline Lötschberg & VS & Railway & 731 & 12 & 305 \\
\hline Mappo-Morettina $^{2}$ & TI & Road & 983 & 16 & 684 \\
\hline Mauvoisin & VS & Investigation tunnel & 600 & 20 & 584 \\
\hline Polmengo & TI & Investigation adit & 600 & 20 & 584 \\
\hline Rawyl & VS & Investigation adit & 1200 & 24 & 1'503 \\
\hline Ricken $^{2}$ & SG & Railway & 1200 & 12 & 501 \\
\hline Simplon (Portal Brigue) & VS & Railway & 1380 & 13 & 672 \\
\hline Vereina & GR & Railway & 2100 & 17 & $1^{\prime} 608$ \\
\hline Total & & & & & $29 ’ 927$ \\
\hline
\end{tabular}

${ }^{1}$ Potential at the portal of the tunnel, without heat pump, cooling up to $6^{\circ} \mathrm{C}$

${ }^{2}$ Usage system in operation

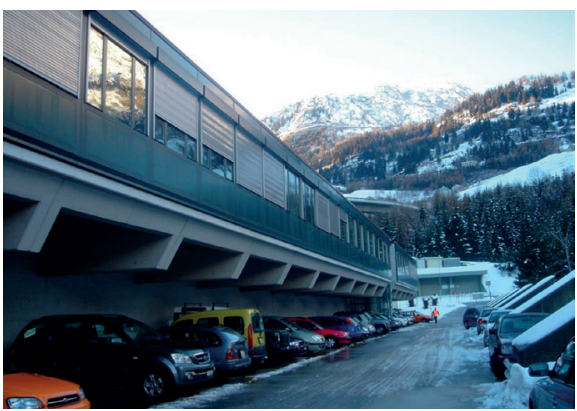

Fig. 4

Airolo/TI - The Entertainment Centre of the Gotthard Road Tunnel at the southern portal has been heated and cooled geothermally since 1979. Tunnel water temperature: $17{ }^{\circ} \mathrm{C}$, thermal capacity with 4 heat pumps: $720 \mathrm{~kW}$ (Photo: Geowatt AG, Zurich)

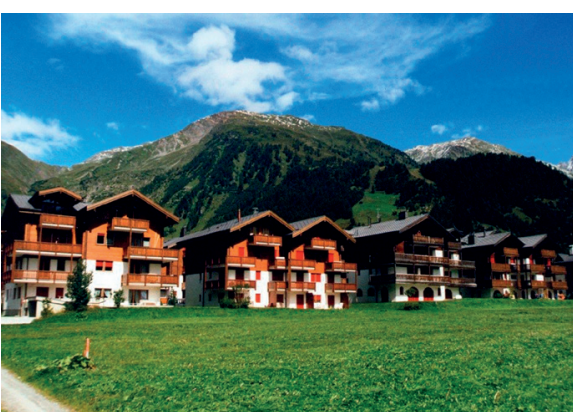

Fig. 5

Oberwald/VS - A distributor network at the western portal of the Furka Rail Tunnel conducts the tunnel water to the heat pumps for each consumer. Tunnel water temperature: $16{ }^{\circ} \mathrm{C}$, thermal capacity: 960 kW (Photo: J. Wilhelm, Pully) 


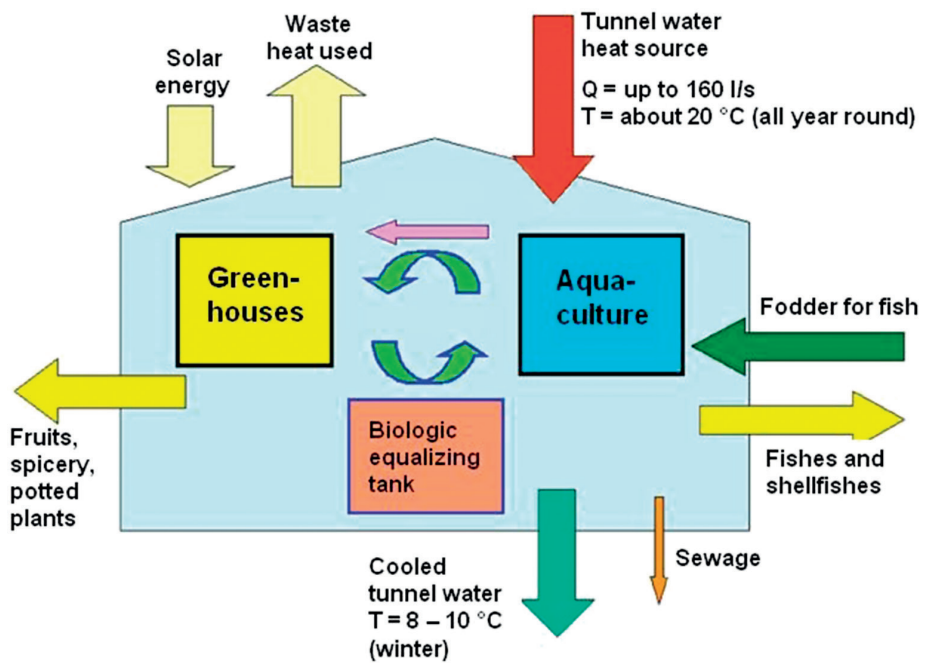

Fig. 6

Frutigen/BE - a "Tropenhaus" as well as a fish raising unit is operating at the northern portal of the Loetschberg Base Tunnel (Source: www.tropenhaus-frutigen.ch)

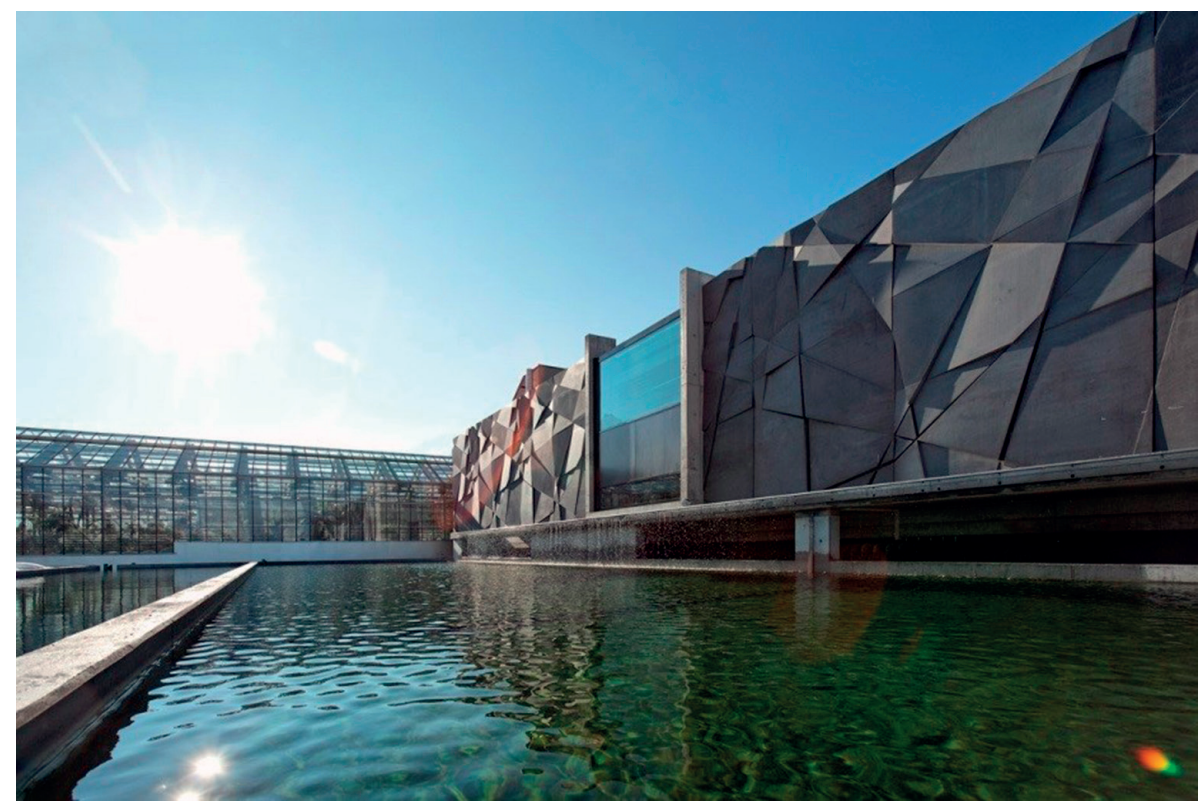

Fig. 7

Warm drainage water from the Loetschberg Base Tunnel $\left(160 \mathrm{l} / \mathrm{s}, 17^{\circ} \mathrm{C}\right)$ is used as the energy base. Fish such as sturgeon and perch, which thrive in warm water, are raised in the Tropenhaus Frutigen fish hatchery basins (in front) as well as tropical fruits are grown in greenhouses (in the back) 
hot tunnel air is used rather than drained water. Examples are to be found in Figs 4, 5, 6 and 7. At Oberwald at the western portal of the Furka Rail Tunnel, the relatively cold tunnel water $\left(16^{\circ} \mathrm{C}\right)$ is conducted in a pipeline to connected buildings ("cold district heating"), where the temperature level required by the heating system is produced by means of heat pumps, designed according to the size of the individual buildings.

An innovative solution: growing tropical fruits in the Alps

There are two major Alpine tunnels (AlpTransit Rail Tunnels) in Switzerland: the Gotthard Base Tunnel $(57 \mathrm{~km}$ long, maximum rock overburden $2.4 \mathrm{~km}$; construction nearly completed) and the Loetschberg Base Tunnel $(35 \mathrm{~km}$, max. overburden 2.0 $\mathrm{km}$, tunnel construction completed, train services operating). Thermal utilization projects have been designed for both tunnels, which are at various stages of implementation/completion.

The Frutigen/BE "Tropenhaus" (= tropical house) Project solves the discharge problem at the northern portal of the Loetschberg Base Tunnel (cf. section on environmental aspects) in a sustainable manner and in this way uses the geothermal heat with an innovative concept. For this project the warm drainage water from the Loetschberg Base Tunnel $\left(1601 / \mathrm{s}, 17^{\circ} \mathrm{C}\right)$ is used as the energy base and cooled down after usage to the desired degree prior to being fed into the local Kander River. Fish such as sturgeon and perch, which thrive in warm water, are raised in the Frutigen Tropenhaus fish hatchery basins; tropical fruits are also grown in greenhouses (Figs 6 and 7). Caviar production is also successfully pursued. By these means, a typical "cascading" use of the tunnel water is realized, sequentially for space heating, greenhouse-growing, and fish farming. The Tropenhaus began to operate in November 2009.

\section{Deep systems: conclusions}

Tunnel heat can be used in different ways. The simplest method directly uses the heat contained by natural flowing water, since deep lying tunnels in some cases drain off large quantities of warm underground water. The thermal power and the outflow temperature at the portal are the determining factors for using flowing tunnel water for energy-related purposes. As far as direct heat utilization is concerned environmental aspects (discharge conditions) as well as economy (heat consumers close to the portals) must be taken into account.

Switzerland, with its many tunnels, possesses an interesting potential for the utilization of warm tunnel waters; various examples have already been accomplished in different parts of the country. Elsewhere other solutions exist such as in Austria, which rely on the direct extraction of rock heat by means of absorber elements and energy anchors (Adam and Oberhauser 2008). In the future, the geothermal use option should duly be taken into account during the early phases of planning for every major tunnel project. 


\section{Concluding remarks}

The earth's interior is an immense heat source and heat store. For practical use the more near-surface parts are of special interest. Shallow and deeper aquifers are especially suitable since the groundwater also acts as heat carrier for the transfer from depth to surface. The relatively high heat capacity of water - when compared to that of rocks - is especially favorable here.

In distinguishing between shallow and deep aquifers the boundary of $400 \mathrm{~m}$ depth is usually applied; see VDI Richtlinie 4640 (2010). Both the shallow and deep aquifers have specific characteristics that are relevant for usage. In the case of the shallow aquifers, groundwater protection issues are of paramount importance. For development, it is essential to secure the necessary permits from the responsible authorities. Deep aquifers mainly supply geothermal district heating systems; here the necessary investment is substantial and the best arrangements can be achieved when community authorities are responsible for establishment and operation.

The presented applications and realization are innovative examples for both categories. Many others are possible and may be developed in the future, since there are many aquifers still untapped for energy-related purposes. In any future use the aspect of sustainability should be strictly followed, in order to secure the longevity of production. Reinjection is especially favorable to keep the balance between heat production and resupply. It is increasingly becoming the standard practice in the energy-related use of deep aquifers. In the coming years, substantial growth can be expected in the sustainable use of shallow and deep aquifers for these purposes.

\section{Acknowledgements}

In the past years the author served as Scientific Advisor for the HYY Company Beijing, China and of the Tropenhaus AG Frutigen, Switzerland. The ability to use many company data for numerous publications is herewith gratefully acknowledged.

\section{References}

Adam, D., A Oberhauser 2008: Kosten und Nutzen der Geothermie für die Verkehrsinfrastruktur. Eisenbahn Ingenieur, 3, pp. 6-12.

Graf, F., L. Rybach, T. Kohl, T. Mégel, R. Sutterlütti, R. Fuchs 2002: Hydraulic-Geothermal Modelling of Koralm Base Tunnel. - Felsbau, 6, pp. 25-32.

Rybach, L. 1995: Thermal waters in deep Alpine tunnels. - Geothermices, 24, pp. 631-637.

Rybach, L. 2005: The advance of geothermal heat pumps world-wide. - IEA Heat Pump Center Newsletter, 23/4, pp. 13-18.

Rybach, L. 2010: Geothermal use of warm tunnel waters - principles and examples from Switzerland. Transactions Geothermal Resources Council, 34, pp. 949-952. 
Rybach, L., Xu, Sheng-heng 2008: How to advance geothermal heat pumps? The examples of Switzerland and the HYY Single Well System in China. - In: Proc. United Nations University Workshop for Decision Makers on direct heating use of geothermal resources in Asia, Tianjin, China, pp. 372-382.

Rybach, L., J. Wilhelm, H. Gorhan 2003: Geothermal use of tunnel waters - a Swiss Specialty. - In: Proc. International Geothermal Conference, Reykjavík, pp. 17-23.

VDI-Richtlinie 4640 2010: Thermische Nutzung des Untergrunds, Blatt 1: Grundlagen, Genehmigungen, Umweltaspekte. - Verein Deutscher Ingenieure, Düsseldorf, 4 p.

Wilhelm, J., L. Rybach 2003: The geothermal potential of Swiss Alpine tunnels. - Geothermics, 32/4-6, pp. 557-568.

Xu, Sheng-heng, L. Rybach 2003: Utilization of shallow resources of direct use systems in Beijing. Transactions Geothermal Resources Council, 27, pp. 115-118.

Xu Sheng-heng, L. Rybach 2004: An innovative, renewable energy system for space heating and cooling - using ubiquitous shallow geothermal resources. - In: Proc. World Renewable Energy Congress, 6 p.

Xu, Sheng-heng, L. Rybach 2006: Operational experience with a new, powerful groundwater heat pump system for space heating and cooling. - In: Proc. Renewable Energy Congress, pp. 1508-1511.

$\mathrm{Xu}$, Sheng-heng, L. Rybach 2010: Innovative groundwater heat pump system for space heating and cooling in USA and China. - In: Proc. World Geothermal Congress, 5 p.

Xu, Sheng-heng, H. Ma, D. Lu 2006: Single Well System technology used in Mongolia. - Transactions Geothermal Resources Council, 30, pp. 110-113.

Xu, Sheng-heng, R. Ling, Y. He, D. Lu 2008: HYY Ground Energy Heat Pump System Used in Waterscape of National Center for the Performing Arts - No-icing on the Waterscape Pool Water Surface in Winter. - Transactions Geothermal Resources Council, 32, pp. 325-331. 